\title{
Öğrencilerin Pazarlama Mesleğini Seçme Nedenlerinin İncelenmesi: Harmancık Meslek Yüksekokulu Örneği
}

Gencay SAATCI

\section{Özet}

$\mathrm{Bu}$ araştırma ile Uludağ Üniversitesi Harmancık Meslek Yüksekokulu bünyesinde bulunan Pazarlama Programında öğrenim gören öğrencilerin bu programı tercih etmelerinde etkili olan öncelikli faktörler değerlendirilmiştir. Öğrencilerinin demografik yapısının belirlenmesi, öğrenim gördükleri programı seçme nedenlerinin ortaya konması, gördükleri pazarlama eğitiminin gelecekle ilgili hedeflerine yönelik uyumluluğunun tespit etmek üzere yapılan çalışma, öğrencilerin tutum ve beklentilerinin tespiti; pazarlama müfredatının geliştirilmesi, ders içeriklerine uygun materyallerin belirlenmesi ve uygun öğretim tekniklerinin yaygınlaştırılması adına önem taşımaktadır.

Araştırma sonucunda bu programı tercih edenlerin büyük çoğunluğunun meslek lisesi mezunu olduğu tespit edilmiştir. Çalışma sonucunda öğrencilerin büyük çoğunluğu bir meslek sahibi olmak için bu bölümü okuduğu ve dikey geçiş yoluyla bir lisans programına devam etmek istediği anlaşılmıştır. Bunun yanı sıra öğrencilerin meslekleri ile ilgili yenilikleri ve gelişmeleri takip etme oranının yüksek olması olumlu yöndedir.

Anahtar Kelimeler: Meslek Seçimi, Meslek Yüksekokulları, Pazarlama Eğitimi.

\section{Analysis Of Causes Students Selecting Marketing Profession: A Sample Of Vocational School Of Harmancik}

\begin{abstract}
By this research efficient factors about why students educating Marketing Program of Uludağ University Harmancık Vocational School prefer this department were assessed. To determine demographic structure of students is important in the way of revealing why students prefer their educating department, studies for determination compatibility of their Marketing Department and their targets for future, determination of
\end{abstract}

\footnotetext{
* Öğretim Görevlisi, Uludağ Üniversitesi, Harmancık Meslek Yüksekokulu
} 
approach and expectation of students, improving of marketing curriculum, determination of required materials for course contents and dissemination of appropriate teaching techniques.

As a result of this research, it is understood that students who prefered this department were graduated from vocational high school. At the end of the study, it was revealed that students educate at this department to have a job and want to continue with a degree program through external transfer exam. Besides, the rate of student's following innovation and development about their job is positive.

Key Words: Choice of Profession, Vocational Schools, Marketing Training.

\section{Giriş}

Rekabet baskısı, teknolojik gelişmeler, işlerin niteliğinin değişmesi ve bunlara bağlı olarak nitelikli personel ihtiyacının artması, insan kaynaklarını işverenlerin öncelikli konularından biri haline getirmiştir (Breaugh ve Starke, 2000: 408; Chan ve Ho, 2000: 320). Bununla birlikte tüketici ihtiyaçlarını en iyi şekilde karşılamak ve pastadan daha fazla pay alabilmek için işletmeler birbiriyle kıyasıya mücadele etmektedirler (Cömert ve Durmaz, 2006: 351). Bu durum işletmelerin teknolojik gelişmelere ayak uydurabilecek bilgi, beceri ve iş alışkanlıklarına sahip iyi eğitilmiş nitelikli iş gücü ihtiyacına olan gereksinimlerini artırmaktadır (Aşkı, 2012: 29).

Ülkemizde farklı alanlarda nitelikli iş gücünün karşılanması amacıyla çıraklık eğitimi, meslek liseleri, meslek yüksekokulları ve üniversite düzeyinde çeşitli eğitim kurumları oluşturulmuştur. Bu kurumlardan meslek yüksekokulları nitelikli ara elemanları yetiştirmesi ve ihtiyacı karşılaması açısından önemli bir yere sahiptir (Aşkı, 2011: 29).

Ülkemizde Meslek Yüksekokulları, mesleki ve teknik eğitimin yükseköğretim kademesindeki en üst kurumudur. Meslek Yüksekokulları, 2547 Sayılı Yükseköğretim Kanunu'nun 20. maddesinde düzenlenen ve iki yıllık ön lisans eğitimi veren yüksekokul statüsünde yükseköğrenim kuruluşlarıdır. Meslek yüksekokullarının üniversite bünyesinde bulunması, bu okulların gelişimi ve vizyonu açısından olumlu bir gelişmedir (Eşme, 2007: 17). Meslek yüksekokulları aslında kendi alanında lise mezunu ile dört yıllık lisans mezunu arasında bir meslekte istihdama yönelik eleman yetiştiren ve aynı zamanda dört yıllık lisans mezunu olabilmek için dikey geçiş yoluyla ileri seviyede yükseköğrenime açık olan yükseköğrenim birimleridir (Çiftçi, 2008: 1). 
Meslek seçimi, bireyin yaşamı boyunca yaptığı seçimler arasında çok önemli bir yer tutmaktadır. Çünkü birey mesleğini seçerken bir bakıma gelecekteki yaşamını da belirlemektedir (Körükçü ve Oğuz, 2011: 78). Bu bağlamda; pazarlama sektöründe çalışmak üzere öğrenim gören öğrencilerin, iş hayatının gerektirdiği biçimde eğitimlerinin verilerek istihdam edilebilirliğinin artırılması ve beceriye sahip vasıflı elemanlar olarak yetiştirilmesinin sağlanması gerekmektedir

\section{Yöntem}

\section{Veri Toplama Araç ve Teknikleri}

Araştırmada veri toplama tekniği olarak yüz yüze görüşme, veri toplama aracı olarak ise; araştırma değişkenlerini ölçmeye yönelik ifadelerin yer aldığ1 anket formu kullanılmıştır. Birinci bölümde öğrencilere ait demografik sorular yer alırken, ikinci bölümde; öğrencilerin öğretim elemanlarının performanslarına bakış açıları ölçülmeye çalışılmış ve son bölümde ise; meslek yüksekokulu tercih etme amacı, gelecekten beklenti, alanında iş bulma ve pazarlama programı hakkındaki genel düşüncelerinin belirlenmesine yönelik önermeler sunulmuştur.

\section{Araştırmanın Yöntemi}

Araştırmada kullanılan anket formu üç bölümden oluşmaktadır. Araştırmada, pazarlama mesleğini ve Harmancık Meslek Yüksekokulu'nu seçim kriterlerinin belirlenmesine yönelik; (1)“Kesinlikle Katılmıyorum” ile (5)“Kesinlikle Katılıyorum” arasında değişen 5'li Likert Ölçeği kullanılmıştır.

Araştırmada elde edilen veriler; birincil veri toplama yöntemlerinden, yüz yüze görüşme yöntemiyle toplanmış olup, soru formu açık ve yapısal olarak düzenlenmiştir. Uygulama yapılan öğrencilerin, araştırmacılar tarafından yüz yüze görüşme yöntemi uygulanması sonucunda deneklerin yorumlarını almak da mümkün olmuştur. Bu durum da çalışmanın araştırmacılar tarafından yorumlanması aşamasında farklı bakış açıları geliştirmelerini sağlamıştır.

\section{Araştırmanın Çerçevesi}

Harmancık Meslek Yüksekokulu Pazarlama Programı öğrencilerinin, pazarlama mesleğini seçme nedenlerinin ve memnuniyet düzeylerinin belirlenmesine yönelik oluşturulan çalışma, ilgili yazında konularla ilgili yapılan çalışmaların örnek alınması suretiyle hazırlanmıştır. 


\section{Evren, Örneklem ve Veri Toplama Süreci Yöntemi}

Araştırma, Uludağ Üniversitesi Harmancık Meslek Yüksekokulu Pazarlama Programı öğrencileri üzerinde yapılmıştır. Araştırmanın evrenini yüksekokuldaki pazarlama programına kayıtlı olan 90 adet öğrenci oluşturmaktadır. Uygulamanın ana kütlesini, pazarlama programına kayıtlı tüm öğrenciler oluşturmaktadır. Ancak ana kütlenin büyüklüğü nedeniyle, çalışmanın örneklemi, Uludağ Üniversitesi Harmancık Meslek Yüksekokulu Pazarlama Programı öğrencileri olarak belirlenmiştir.

Elde edilen veriler değerlendirildiğinde; söz konusu öğrencilerin tümünün çalışmayı destekleyecek niteliklerde rasyonel ve sağlıklı veriler verdiği saptanmıştır. Araştırma verileri 2012 yılı Nisan ayında toplanmıştır.

\section{Çalışmanın Kısıtları}

Araştırmanın en önemli kısıtı maliyettir. Anket uygulamasının tüm evrende uygulanabilmesinin maliyeti oldukça yüksek olacağ i için örneklem büyüklüğü asgari düzeyde tutulmuştur.

\section{Analiz ve Bulguların Yorumlanması}

Yapilan anketler SPSS (Statistical Package for Social Sciences, Version 20) programına aktarılmış ve araştırma analizleri bu programda tamamlanmıştır. Buna göre; elde edilen ham verilerin analizinden sonra ortaya çıkan istatistikî sonuçlar ve yorumları şu şekildedir:

Tablo 1: Güvenilirlik Analizi Testi

\begin{tabular}{|c|c|}
\hline Cronbach's Alpha & N of Items \\
\hline, 755 & 33 \\
\hline
\end{tabular}

Program, analizleri ortalama \% 76 güven düzeyinde gerçekleştirmektedir. Bu durum da; yapılan çalışmanın istatistikî olarak kabul edilebilir sınırlar dâhilinde şekillendiği sonucunu ortaya çıkarmaktadır.

\section{Tablo 2: Uygulama Yapılan Öğrencilere Ait Değişkenler}

Öğrencilerin cinsiyetleri, yaşları, genel not ortalamaları, mezun oldukları lise türleri, ailelerinin yaşadığı yerleşim yerleri ve gelir 
Uşak Üniversitesi Sosyal Bilimler Dergisi $2013,6 / 3$

G. SAATCI

düzeylerine ilişkin değerleri tespit edilmiştir. Tablo 2'de ise öğrencilerin demografik özellikleri ile ilgili veriler sunulmaktadır.

\begin{tabular}{|c|c|c|}
\hline Değişkenler & $\begin{array}{c}\text { Sıklık } \\
(N)\end{array}$ & Yüzde Değeri (\%) \\
\hline \multicolumn{3}{|l|}{ I. BÖLÜM } \\
\hline \multicolumn{3}{|l|}{ Cinsiyet } \\
\hline Kadın & 37 & 41,1 \\
\hline Erkek & 53 & 58,9 \\
\hline TOPLAM & 90 & 100 \\
\hline \multicolumn{3}{|l|}{ Öğrenim Türü } \\
\hline Örgün Öğretim & 69 & 76,7 \\
\hline İkinci Öğretim & 21 & 23,3 \\
\hline TOPLAM & 90 & 100 \\
\hline \multicolumn{3}{|l|}{ Yaş } \\
\hline 16-20 Arasi & 38 & 42,2 \\
\hline 21-25 Arasi & 51 & 56,7 \\
\hline 26-30 Arasi & 1 & 1,1 \\
\hline 31 ve Üzeri & - & - \\
\hline TOPLAM & 90 & 100 \\
\hline \multicolumn{3}{|l|}{ Genel Not Ortalaması } \\
\hline 0,00-0,99 Aras1 & 11 & 12,2 \\
\hline 1,00-1,99 Arasi & 35 & 38,9 \\
\hline 2,00-2,99 Aras1 & 33 & 36,7 \\
\hline 3,00-4,00 Arası & 11 & 12,2 \\
\hline TOPLAM & 90 & 100 \\
\hline \multicolumn{3}{|l|}{ Mezun Olunan Lise Türü } \\
\hline Düz Lise & 40 & 44,4 \\
\hline Meslek Lisesi & 47 & 52,2 \\
\hline Anadolu Lisesi & 3 & 3,3 \\
\hline TOPLAM & 90 & 100 \\
\hline \multicolumn{3}{|l|}{ Aile İkamet Yeri } \\
\hline Büyükşehir & 49 & 54,4 \\
\hline Şehir & 18 & 20,0 \\
\hline İlçe & 19 & 21,1 \\
\hline Belde & 1 & 1,1 \\
\hline Köy & 3 & 3,3 \\
\hline TOPLAM & 90 & 100 \\
\hline \multicolumn{3}{|c|}{ Ailede Pazarlama Mesleği Yapan Birey } \\
\hline
\end{tabular}


Uşak Üniversitesi Sosyal Bilimler Dergisi

$2013,6 / 3$

G. SAATCI

\begin{tabular}{|c|c|c|}
\hline Evet & 19 & 21,1 \\
\hline Hayır & 71 & 78,9 \\
\hline TOPLAM & 90 & 100 \\
\hline \multicolumn{3}{|l|}{ Öğrenci İkamet Yeri } \\
\hline Aile Yanı & 16 & 17,8 \\
\hline Öğrenci Evi & 39 & 43,3 \\
\hline Devlet Yurdu & 24 & 26,7 \\
\hline Özel Yurt & 11 & 12,2 \\
\hline TOPLAM & 90 & 100 \\
\hline \multicolumn{3}{|l|}{ Bölüm Memnuniyet Durumu } \\
\hline İsteyerek Yazdım Memnunum & 44 & 48,9 \\
\hline İsteyerek Yazdım, Memnun Değilim & 13 & 14,4 \\
\hline İstemeyerek Yazdım, Memnunum & 23 & 25,6 \\
\hline $\begin{array}{l}\text { İstemeyerek Yazdım, Memnun } \\
\text { Değilim }\end{array}$ & 10 & 11,1 \\
\hline TOPLAM & 90 & 100 \\
\hline \multicolumn{3}{|l|}{ Aile Gelir Düzeyi } \\
\hline $250-500 \mathrm{TL}$ & 1 & 1,1 \\
\hline $501-750 \mathrm{TL}$ & 8 & 8,9 \\
\hline 751-1000 TL & 26 & 28,9 \\
\hline 1001-1250 TL & 32 & 35,6 \\
\hline 1251 TL ve üzeri & 23 & 25,6 \\
\hline TOPLAM & 90 & 100 \\
\hline \multicolumn{3}{|l|}{ Aylık Harçlık } \\
\hline $0-250 \mathrm{TL}$ & 17 & 18,9 \\
\hline $251-500 \mathrm{TL}$ & 50 & 55,6 \\
\hline $501-750 \mathrm{TL}$ & 17 & 18,9 \\
\hline 751-1000 TL & 5 & 5,6 \\
\hline 1001 TL ve üzeri & 1 & 1,1 \\
\hline TOPLAM & 90 & 100 \\
\hline
\end{tabular}

\begin{tabular}{|c|c|c|}
\hline \multicolumn{3}{|c|}{ Öğretim Elemanlarını Değerlendirme } \\
\hline \multicolumn{3}{|c|}{ Öğretim Elemanlarının Performansı } \\
\hline Yeterli & 52 & 57,8 \\
\hline Kismen Yeterli & 35 & 38,9 \\
\hline Yeterli Değil & 3 & 3,3 \\
\hline TOPLAM & 90 & 100 \\
\hline
\end{tabular}




\begin{tabular}{|c|c|c|}
\hline Yeterli & 50 & 55,6 \\
\hline Kismen Yeterli & 35 & 38,9 \\
\hline Yeterli Değil & 5 & 5,6 \\
\hline TOPLAM & 90 & 100 \\
\hline \multicolumn{3}{|c|}{ Öğretim Elemanlarının Ders Dışı İlişkileri } \\
\hline Yeterli & 35 & 38,9 \\
\hline Kısmen Yeterli & 30 & 33,3 \\
\hline Yeterli Değil & 25 & 27,8 \\
\hline TOPLAM & 90 & 100 \\
\hline
\end{tabular}

Not: Yüzdeler en yakın değere yuvarlanmıştır.

Araştırmaya katılan öğrencilerin \%41,1'i (37 kişi) kadın, \%58,9'u (53 kişi) erkektir. Öğrenim türlerine göre ayrım yapıldığında ise \%76,7'si (69 kişi) örgün öğretim, \%23,3'ü (21 kişi) de ikinci öğretim öğrencisidir. Yaş aralıklarına göre incelendiğinde ise; $16-20$ yaş arası $38(\% 42,2)$ kişi, $21-25$ yaş arası $51(\% 56,7)$ kişi, 26-30 yaş arası $1(\% 1,1)$ kişi bulunmaktadır. Öğrencilerin genel not ortalamaları incelendiğinde de; 0,00-1,00 arası 11 kişi (\%12,2), 1,01-2,00 arası 35 kişi (\%38,9), 2,01-3,00 arası 33 kişi (\%36,7), 3,014,00 arası 11 kişi $(\% 12,2)$ yer almaktadır. Mezun olunan lise türüne göre sınıflandırıldığında; \%52,2 (47 kişi) meslek lisesi, \%44,4 (40 kişi) düz lise, \%3,3 (3 kişi) anadolu lisesi mezuniyetine sahiptir.

Öğrencilerin aile ikamet yerleri incelendiğinde ise; \%54,4'ü (49 kişi) büyükşehirde, \%20'si (18 kişi) şehirde, \%21,1'i (19 kişi) ilçede, \%1,1'i (1 kişi) beldede ve \%3,3'ü de (3 kişi) köyde ikamet etmektedir. Öğrencilerin Harmancık'ta ikamet ettikleri yerler ise sırasıyla şu şekildedir; \%43,3'ü (39 kişi) öğrenci evi, \%26,7'si (24 kişi) devlet yurdu, \%17,8'si (16 kişi) aile yanında ve \%12,2'si (11 kişi) de özel yurtta kalmaktadırlar. Öğrencilerin ailelerinde pazarlama mesleğini yapan birey olup olmadığı araştırıldığında ise; \%78,9'u (71 kişi) olmadığını, \%21,1'i (19 kişi) de olduğunu belirtmişlerdir.

Bölüm memnuniyet durumları incelendiğinde ise; \%48,9'u (44 kişi) isteyerek yazıp memnun olduklarını, \%25,6'sı (23 kişi) istemeyerek yazıp memnun olduklarını, \%14,4'ü (13 kişi) isteyerek yazıp memnun olmadıklarını ve \%11,1'i (10 kişi) de istemeyerek yazıp aynı zamanda da memnun olmadıklarını vurgulamışlardır. Aile gelir düzeyleri incelendiğinde ise; \%35,6'sı (32 kişi) 1001-1250 TL, \%28,9'u (26 kişi) 751-1000 TL, \%25,6's (23 kişi) 1251 TL ve üzeri, \%8,9'u (8 kişi) 501-750 TL, \%1,1'i (1 kişi) de 250500 TL gelirleri olduğunu belirtmişlerdir. Öğrencilerin aylık ortalama 
harçlıkları sorulduğunda ise; \%55,6'sı (50 kişi) 251-500 TL, \%18,9'u (17 kişi) 501-750 TL, yine \%18,9'u (17 kişi) 0-250 TL, \%5,6'sı (5 kişi) 751-1000 TL, \%1,1'i (1 kişi) de 1001 TL ve üzeri harcamaları olduğunu belirtmişlerdir.

Öğretim elemanlarını değerlendirmeleri aşamasında ortaya çıkan sonuçlar ise şu şekildedir; öğretim elemanlarının performansını 52 kişi, $(\% 57,8)$ yeterli, 35 kişi $(\% 38,9)$ kısmen yeterli ve 3 kişi $(\% 3,3)$ de yetersiz bulmuştur. Öğretim elemanlarının ders içi ilişkilerini 50 kişi $(\% 55,6)$ yeterli, 35 kişi $(\% 38,9)$ kısmen yeterli ve 5 kişi $(\% 5,6)$ de yetersiz bulmuştur. Öğretim elemanlarının ders dışı ilişkileri incelendiğinde ise; 35 kişi $(\% 38,9)$ yeterli, 30 kişi $(\% 33,3)$ kısmen yeterli, 25 kişi $(\% 27,8)$ de yetersiz bulmuştur.

Tablo 3: Önermelere İlişkin Analiz Sonuçları

\begin{tabular}{|c|c|c|}
\hline ÖNERMELER & A.O. & S.S. \\
\hline \multicolumn{3}{|l|}{ STAJLAR } \\
\hline 1. Çalışma yaşamına hazırlanmak için bir fırsattır. & 4,47 & ,902 \\
\hline 2. Sektörü tanıma şansı yaratır. & 4,42 & ,749 \\
\hline 3. Yeni bilgiler öğrenme imkânı sunar. & 4,39 & 817 \\
\hline $\begin{array}{l}\text { 4. Okulda öğrenilen bilgilerin uygulamada nasıl } \\
\text { işlediğini görme şansı yaratır. }\end{array}$ & 3,91 & 1,186 \\
\hline $\begin{array}{l}\text { 5. Stajlar sadece yapilmasi gereken bir } \\
\text { zorunluluktur. }\end{array}$ & 2,54 & 1,367 \\
\hline \multicolumn{3}{|l|}{ MYO OKUMADAKİ AMAÇ } \\
\hline 6. Bir meslek sahibi olmak istiyorum. & 4,27 & 1,140 \\
\hline 7. Ailem istediği için okuyorum. & 3,83 & 1,343 \\
\hline $\begin{array}{l}\text { 8. DGS yoluyla bir fakülteye yerleşmeyi } \\
\text { düşünüyorum. }\end{array}$ & 3,56 & 1,462 \\
\hline 9. Üniversite eğitimi almak için okuyorum. & 1,80 & 1,144 \\
\hline 10. Mesleğimde kariyer yapmak istiyorum. & 3,60 & 1,322 \\
\hline \multicolumn{3}{|l|}{ MYO OKUMANIN SAĞLADIĞI KATKI } \\
\hline 11. Toplumda statü kazanma sağlar. & 2,48 & 1,292 \\
\hline 12. Mesleki açıdan gelişim yaratır. & 4,00 & 1,218 \\
\hline 13. Sadece diplomaya sahip olunur. & 2,79 & 1,285 \\
\hline 14. Bir katkı sağlamayacağını düşünüyorum. & 2,00 & 1,236 \\
\hline \multicolumn{3}{|l|}{ GELECEKTEN BEKLENTI } \\
\hline 15. Mesleğim ile ilgili bir işte çalışabilirim. & 2,46 & 1,447 \\
\hline 16. Herhangi bir işte çalışabilirim. & 3,12 & 1,297 \\
\hline 17. Bu alanda başarısız olacağımı sanıyorum. & 1,87 & 1,073 \\
\hline MEZUN OLDUKTAN SONRA ALANINDA İ & 3ULM & \\
\hline
\end{tabular}




\begin{tabular}{|c|c|c|}
\hline 18. İş bulamayacağımı düşünüyorum. & 3,72 & 1,209 \\
\hline $\begin{array}{l}\text { 19. İş̧ bulma konusunda özgüvenimin eksik } \\
\text { olduğunu düşünüyorum. }\end{array}$ & 2,03 & 1,575 \\
\hline $\begin{array}{l}\text { 20. Piyasa şartlarının çok zorlu olduğunu } \\
\text { düşünüyorum. }\end{array}$ & 3,14 & 1,481 \\
\hline $\begin{array}{l}\text { 21. Fakülte mezunlarının tercih edilebilirlik oranları } \\
\text { daha yüksektir. }\end{array}$ & 3,77 & 1,218 \\
\hline \multicolumn{3}{|l|}{ HARMANCIK MYO SEÇIM NEDENLERİ } \\
\hline $\begin{array}{l}\text { 22. Kişisel özelliklerim pazarlama mesleğine } \\
\text { yatkındır. }\end{array}$ & 3,94 & 1,174 \\
\hline $\begin{array}{l}\text { 23.Uludă̆ Üniversitesinin eğitim kalitesinin ve } \\
\text { mezunlarının iş bulma kapasitesinin yüksek } \\
\text { olmasıdır. }\end{array}$ & 4,01 & ,989 \\
\hline $\begin{array}{l}\text { 24. Aldığım LYS puanının bu bölüme girmeye } \\
\text { yetmesidir. }\end{array}$ & 3,67 & 1,315 \\
\hline $\begin{array}{l}\text { 25. Harmancık ilçesinin memleketim olması / } \\
\text { memleketime yakın olmasıdır. }\end{array}$ & 3,74 & 1,362 \\
\hline \multicolumn{3}{|c|}{ PAZARLAMA PROGRAMI GENEL DEĞERLENDİRME } \\
\hline $\begin{array}{l}\text { 26.Pazarlama dersleri, toplum ve tüketici ilişkisini } \\
\text { kavrayabilmek açısından faydalıdır. }\end{array}$ & 3,07 & 1,261 \\
\hline $\begin{array}{l}\text { 27. Pazarlama derslerinde öğretilen konular günlük } \\
\text { hayatta kullanılabilir niteliktedir. }\end{array}$ & 3,94 & 1,284 \\
\hline $\begin{array}{l}\text { 28. Pazarlama dersleri uygulamadan çok teori } \\
\text { ağırlıklıdır. }\end{array}$ & 4,47 & ,902 \\
\hline $\begin{array}{l}\text { 29. Pazarlamanın diğer işletme unsurları ile olan } \\
\text { ilişkisini öğrenmek açısından pazarlama dersleri } \\
\text { faydalıdır. }\end{array}$ & 4,42 & ,749 \\
\hline $\begin{array}{l}\text { 30. Pazarlama derslerini zorunlu olmasa da almak } \\
\text { isterdim. }\end{array}$ & 4,39 & 817 \\
\hline $\begin{array}{l}\text { 31.Pazarlama programının kariyer imkânları oldukça } \\
\text { geniştir. }\end{array}$ & 3,91 & 1,186 \\
\hline $\begin{array}{l}\text { 32. Pazarlamada etik olmayan birçok uygulama } \\
\text { vardır. }\end{array}$ & 2,54 & 1,367 \\
\hline 33. Satış ve pazarlama zor değildir ve eğlencelidir. & 3,94 & 1,284 \\
\hline
\end{tabular}

Önermeler; stajlar, MYO okumadaki amaç, MYO okumanın sağladığı katkı, gelecekten beklenti, mezun olduktan sonra alanında iş bulma, Harmancık MYO seçim nedenleri ve pazarlama programı genel değerlendirme adı altında sıralanmış ve bu sıralamaya göre analiz edilmiştir. Yapılan değişken analizi sonucunda verilen başlıklara göre 
aritmetik ortalama ve standart sapmalarına göre ön plâna çıkan önermeler şu şekildedir:

Stajlar başlığı altında "Çalı̧̧ma yaşamına hazırlanmak için bir fırsattır." ifadesine en yüksek oranda katılım gözlenmiştir. "Stajlar sadece yapılması gereken bir zorunluluktur." ifadesine de en düşük oranda katılım gözlenmiştir.

MYO okumadaki amaç kategorisinde "Bir meslek sahibi olmak istiyorum." önermesine en yüksek katılım gerçekleşirken; "Üniversite eğitimi almak için okuyorum." önermesinin en düşük katılım oranına sahip olduğu ortaya çıkmıştır.

MYO okumanın sağladığı katkı başlığı altında "Mesleki açıdan gelişim yaratır." ifadesine yüksek bir katılım gözlenirken, "Bir katkı sağlamayacağını düşünüyorum." ifadesine de en düşük oranda katılım söz konusudur.

Gelecekten beklenti sınıflandırması altındaki önermeler incelendiğinde de "Herhangi bir işte çalışabilirim." ifadesi büyük oranda katılımın sağlandığı ifade olurken "Bu alanda başarısız olacağımı saniyorum." ifadesi de düşük bir oran göstermektedir.

Mezun olduktan sonra alanında iş bulma başlığı altında, "Fakülte mezunlarının tercih edilebilirlik oranları daha yüksektir." önermesi en yüksek katılımlı önerme olurken, "İş bulma konusunda özgüvenimin eksik olduğunu düşünüyorum." önermesi de en düşük katılımlı önerme olarak göze çarpmaktadır.

Harmancık MYO seçim nedenleri kategorisi incelendiğinde de; "Uludağ Üniversitesinin eğitim kalitesinin ve mezunlarının iş bulma kapasitesinin yüksek olmasıdır." ifadesine yüksek bir katılım gözlenirken, "Aldığım LYS puanının bu bölüme girmeye yetmesidir." ifadesinin düşük bir katılıma sahip olduğu gözlemlenmiştir.

Son olarak pazarlama programı genel değerlendirme kategorisinde, "Pazarlama dersleri uygulamadan çok teori ağırlıklıdır." önermesi en yüksek oranda katılıma sahip olurken; "Pazarlamada etik olmayan birçok uygulama vardır." önermesi de en düşük katılımlı önerme olarak ortaya çıkmıştır. 
Uşak Üniversitesi Sosyal Bilimler Dergisi

Tablo 4. Değişkenlerin Regresyon Analizleri

\begin{tabular}{|c|c|c|}
\hline \multicolumn{3}{|c|}{ Not Ortalaması } \\
\hline İş Bulma 1 & Pearson Correlation & ,371(**) \\
\hline İş bulamayacă̆ımı düşünüyorum. & Sig. (2-tailed) & ,000 \\
\hline \multicolumn{3}{|c|}{ Not Ortalaması } \\
\hline İş Bulma 2 & Pearson Correlation &,$- 235(*)$ \\
\hline $\begin{array}{l}\dot{I}_{S ̧} \text { bulma konusunda özgüvenimin eksik } \\
\text { olduğunu düşünü̈yorum. }\end{array}$ & Sig. (2-tailed) & ,026 \\
\hline \multicolumn{3}{|c|}{ Not Ortalamasi } \\
\hline İş Bulma 3 & Pearson Correlation &,$- 209(*)$ \\
\hline $\begin{array}{l}\text { Piyasa şartlarının çok zorlu olduğunu } \\
\text { düşünüyorum. }\end{array}$ & Sig. (2-tailed) & ,048 \\
\hline \multicolumn{3}{|c|}{ Not Ortalamasi } \\
\hline MYO Seçim 3 & Pearson Correlation &,$- 260(*)$ \\
\hline $\begin{array}{l}\text { Aldığım LGS puanı bu bölüme girmeye } \\
\text { yetmesidir. }\end{array}$ & Sig. (2-tailed) & ,013 \\
\hline \multicolumn{3}{|c|}{ Not Ortalamas1 } \\
\hline Pazarlama 4 & Pearson Correlation & ,211(*) \\
\hline $\begin{array}{l}\text { Pazarlamanın diğer işletme unsurları ile olan } \\
\text { ilişkisini öğrenmek açısından pazarlama dersleri } \\
\text { faydalıdır. }\end{array}$ & Sig. (2-tailed) & ,046 \\
\hline \multicolumn{3}{|c|}{ Not Ortalamasi } \\
\hline Pazarlama 5 & Pearson Correlation &, $264(*)$ \\
\hline $\begin{array}{l}\text { Pazarlama derslerini zorunlu olmasa da almak } \\
\text { isterdim. }\end{array}$ & Sig. (2-tailed) & ,012 \\
\hline \multicolumn{3}{|c|}{ Aile Yerleşim } \\
\hline İş Bulma 3 & Pearson Correlation & ,238(*) \\
\hline $\begin{array}{l}\text { Piyasa şartlarının çok zorlu olduğunu } \\
\text { düşünüyorum. }\end{array}$ & Sig. (2-tailed) & ,024 \\
\hline \multicolumn{3}{|c|}{ Memnuniyet } \\
\hline Amaç 5 & Pearson Correlation &,$- 231(*)$ \\
\hline Mesleğimde kariyer yapmak istiyorum. & Sig. (2-tailed) & ,028 \\
\hline \multicolumn{3}{|c|}{ Memnuniyet } \\
\hline MYO Seçim 1 & Pearson Correlation & ,274(**) \\
\hline $\begin{array}{l}\text { Kişisel özelliklerim pazarlama mesleğine } \\
\text { yatkındır. }\end{array}$ & Sig. (2-tailed) & ,009 \\
\hline \multicolumn{3}{|c|}{ Memnuniyet } \\
\hline MYO Seçim 2 & Pearson Correlation &,$- 246(*)$ \\
\hline Uludă̆ Üniversitesinin eğitim kalitesinin ve & Sig. (2-tailed) &, 019 \\
\hline
\end{tabular}




\begin{tabular}{|c|c|c|}
\hline $\begin{array}{l}\text { mezunlarının iş bulma kapasitesinin yüks } \\
\text { olmasıdır. }\end{array}$ & & \\
\hline \multicolumn{3}{|c|}{ Memnuniyet } \\
\hline Pazarlama 5 & Pearson Correlation &,$- 213(*)$ \\
\hline $\begin{array}{l}\text { Pazarlama derslerini zorunlu olmasa da almak } \\
\text { isterdim. }\end{array}$ & Sig. (2-tailed) & ,044 \\
\hline \multicolumn{3}{|c|}{ Aile Gelir Düzeyi } \\
\hline İş Bulma 3 & Pearson Correlation &,$- 243(*)$ \\
\hline $\begin{array}{l}\text { Piyasa şartlarının çok zorlu olduğunu } \\
\text { düşünüyorum. }\end{array}$ & Sig. (2-tailed) & ,021 \\
\hline \multicolumn{3}{|c|}{ Aylık Harçlık } \\
\hline Amaç 1 & Pearson Correlation &,$- 227(*)$ \\
\hline Bir meslek sahibi olmak istiyorum. & Sig. (2-tailed) & ,031 \\
\hline
\end{tabular}

Yapılan regresyon analizi sonucunda ise; bağımsız değişkenler, genel not ortalaması, aile yerleşim yeri, bölüm memnuniyet durumu, aile gelir düzeyi ve aylık harçlık ile bağımlı değişkenler olan, stajlar, MYO okumadaki amaç, MYO okumanın sağladığı katkı, gelecekten beklenti, mezun olduktan sonra alanında iş bulma, Harmancık MYO seçim nedenleri ile pazarlama programının genel olarak katkısını belirlemeye yönelik önermeler arasındaki ilişki düzeyleri şu şekilde ortaya çıkmıştır:

Genel not ortalaması ile "İş bulamayacağımı düşünüyorum.", "İş bulma konusunda özgüvenimin eksik olduğunu düşünüyorum", "Piyasa şartlarının çok zorlu olduğunu düşünüyorum." ve "Aldığım LYS puanı bu bölüme girmeye yetmesidir." önermeleri arasında negatif yönlü bir ilişki olduğu saptanmıştır. Yine genel not ortalaması ile "Pazarlamanın diğer işletme unsurları ile olan ilişkisini öğrenmek açısından pazarlama dersleri faydalıdır."ve "Pazarlama derslerini zorunlu olmasa da almak isterdim." önermeleri arasında pozitif yönde anlamlı ilişki olduğu saptanmıştır.

Aile yerleşim yeri ile "Piyasa şartlarının çok zorlu olduğunu düşünüyorum." önermesi arasında pozitif yönde anlamlı ilişki olduğu görülmektedir.

Bölüm memnuniyet durumu ile "Mesleğimde kariyer yapmak istiyorum.", "Kişisel özelliklerim pazarlama mesleğine yatkındır.", "Uludağ Üniversitesinin eğitim kalitesinin ve mezunlarının iş bulma kapasitesinin yüksek olmasıdır." ve "Pazarlama derslerini zorunlu olmasa da almak isterdim." önermeleri arasında negatif yönlü ilişki olduğu saptanmıştır.

Aile gelir düzeyi ile "Piyasa şartlarının çok zorlu olduğunu düşünüyorum." önermesi ve öğrencinin aylık harçlık durumu ile "Bir 
meslek sahibi olmak istiyorum." önermesi arasında negatif yönlü bir ilişki olduğu ortaya çıkmıştır.

\section{Sonuç ve Öneriler}

Çalışmada Uludağ Üniversitesi Harmancık Meslek Yüksekokulu Pazarlama Programındaki öğrencilerin genel yapısının, bu programı tercih etme nedenlerinin, derslerle ilgili görüşlerinin ve gelecekle ilgili planlarında meslek yüksekokulun etkisinin ve memnuniyet düzeylerinin belirlenmesi için anket uygulaması gerçekleştirilmiştir. Ankete verilen yanıtlar değerlendirilerek şu sonuçlara ulaşılmıştır:

Bireyin yaptığı mesleği sevmesi ve saygı duyması, bireyin kendine güven duyarak, yaptığı işten doyum duymasını ve hayattan zevk almasını sağlar. Pazarlama mesleğine karşı meslek saygısı oluşması için, mesleğin sosyal ve ekonomik koşullarının daha iyi hale getirilmesinin yararlı olacağ düşünülmektedir.

Ülkemizde meslek yüksekokullarının, mesleki ve teknik eğitimin yükseköğretim kademesindeki en üst kurumu durumunda olmasının yanında; bir meslekte istihdama yönelik eleman yetiştiren ve dikey geçiş yoluyla yükseköğrenime açı olan birimlerdir. Kariyer tercihi konusunda, LYS sonucuna göre öğrenciler kimi zaman arzu ettikleri, kendilerine uygun olan bölümlerde, kimi zamanda puanlarının yettiği, ama kendilerine çok da uygun olmayan bölümlerde eğitimlerine devam etmek zorunda kalmaktadırlar. Bu durum da öğrencilerin memnuniyet düzeylerini azaltan bir etki olarak karşımıza çıkmaktadır. Fakat diğer taraftan ankete katılan öğrencilerin mezun oldukları lise türünün çoğunluğunun meslek lisesi olması da önceden belirlenmiş bir kariyer hedeflerinin olduğunun göstergesidir.

Kaliteli eğitimin önkoşullarından biri olan öğrencilerin derse ilgilerinin arttırılması ve öğrencilerin başarı oranlarının yükseltilmesi için her öğrencinin kendi ilgi ve yetenekleri doğrultusunda bir mesleğe yönlendirilmesi için ilköğretimden itibaren mesleki yönlendirme programlarının daha işlevsel duruma getirilmesi için çalışmalar yapılabilir.

Genel olarak bakıldığında da öğrencilerin büyük bir çoğunluğunun programlarını isteyerek yazdıkları ve memnun olduklarını belirtmişlerdir. Bununla birlikte öğretim elemanlarını değerlendirme aşamasında verilen yanitlar göz önünde bulundurulduğunda, genel olarak öğretim elemanlarının performansını, ders içi ve ders dışı ilişkilerini yeterli bulduklarını ifade etmişlerdir. Dolayısıyla bu faktörler de öğrencilerin 
memnuniyet düzeylerini doğrudan etkiledikleri için her kurumun kendi bünyesinde belirli aralıklarla bu tür değerlendirmeler yaparak mevcut durum hakkında veriler elde ederek aksayan taraflar hakkında düzeltme yapma imkânı bulabileceklerdir.

Uygulamaya katılan öğrencilerin büyük çoğunluğunun aile ikamet yerinin büyükşehir olması ve fakülte mezunlarının tercih edilebilirlik oranlarının daha yüksek olması öğrencilerin gelecekten beklentileri ve iş bulma konusunda özgüven eksikliklerinin ortaya çıktığının göstergesidir. $\mathrm{Bu}$ durum karşısında, iş hayatlarında karşılarına çıkabilecek rakiplerinin niteliklerinden daha fazlasını elde etmeleri gerektiği, öğrencilerin eğitimlerine lisans düzeyinde devam etmeleri ya da kendi bilgi, beceri ve niteliklerini olabildiğince geliştirmeleri gerektiği konusunda bilinçlenmeleri sağlanmalıdır.

Genel olarak değerlendirildiğinde ise; öğrencilerin Harmancık Meslek Yüksekokulu'nu seçim kriterleri arasında Uludağ Üniversitesinin eğitim kalitesinin ve mezunlarının iş bulma kapasitesinin yüksek olması bulunmaktadır. Söz konusu durum öğrencilerin geleceğe daha güven ile bakmalarını sağlarken öğrenim gördükleri programdan memnuniyet düzeylerini artırmakta ve mesleklerini sevmelerini sağlamaktadır.

\section{Kaynakça}

AŞKI, Ayşin, (2012), Myo Mobilya ve Dekorasyon Programı Öğrencilerinin $\mathrm{Bu}$ Programı Tercih Etme Nedenlerinin ve Memnuniyet Durumlarının Araştırılması: Çomu Örneği. Düzce Üniversitesi Orman Fakültesi, Ormancilık Dergisi, Cilt: 7, Sayı: 2, 28-38.

BREAUGH, J. A. ve STARKE, M. (2000), Research on Employee Recruitment: So Many Studies, So Many Remaining Questions. Journal of Management, 26: 405-434.

CHAN, S. Y. ve HO, S. M. (2000), Desired Attributes of Public Accounting Firms in The Job Selection Process: An Empirical Examination Of Accounting Graduates' Perceptions. Accounting Education, 9 (4) s.315-327.

CÖMERT, Yavuz ve Yakup DURMAZ, (2006), Tüketicinin Tatmini İle Satın Alma Davranışlarını Etkileyen Faktörlere Bütünleşik Yaklaşım ve Adıyaman İlinde Bir Alan Çalışması. Journal of Yasar University, 1 (4), 351-375. 
Uşak Üniversitesi Sosyal Bilimler Dergisi

ÇífÇİ, Ahmet, (2008), Önlisans Eğitimi Veren Meslek Yüksekokulları Üzerine Bir Değerlendirme Raporu, III. Ulusal Meslek Yüksek Okulları Müdürler

http://myotoplantisi.cu.edu.tr/komisyon1/yanikogludenktaskomisyonI.doc., Erişim Tarihi: 12.06.2012.

EŞME, İsa, (2007), Türkiye'de Mesleki ve Teknik Eğitimin Bugünkü Durumu ve Sorunları. Uluslararası Mesleki ve Teknik Eğitim Konferansı Bildiri Kitabı, Yükseköğretim Kurulu Yayını.

KÖRÜKÇÜ, Özlem ve Vuslat OĞUZ, (2011), Okul Öncesi Eğitimi Öğretmen Adaylarının Mesleki Benlik Saygıları. Kurumsal Ĕ̆itimbilim, 4 (2), 7785. 